\title{
A comet called Genin
}

\section{Alexej Rodionov}

Independent researcher, Saint Petersburg

Email rodionofff@yandex.ru

\begin{abstract}
The article is devoted to the artistic development and biography of the painter and illustrator Robert Genin (1884-1941), who was born in Belarus, studied art in Vilnius, Odessa, Munich and Paris, lived in Paris, Munich, Ascona and Moscow, created numerous paintings, illustrations and some frescos.

KEYWORDS: Robert Genin, artist, suicide, painting, drawing, fresco, exhibition, neoclassicism, expressionism, Mogilev, Vilna, Odessa, Munich, Berlin, Ascona, Bali, Paris, Moscow
\end{abstract}

'It was a short story about the man, who passed through like a comet - our dear Robert L'vovich Genin'. This phrase finishes the memoirs of his friend, artist Alexander Mogilevsky.

Robert Genin (1884-1941) was an artist whose life was greatly determined by both World wars. Due to his rapid movements from city to city, from country to country, he came into a certain gap between the people who knew and liked him. He committed suicide shortly after the break-down of the World War II, and there were no more people who would actively promote his art. This is the reason for lacking attention to his art after his death. The first attempts to show works of Genin were made by Ralph Jentsch in 1969, 1977 und 1980. Each of these exhibitions was accompanied by a booklet ${ }^{1}$, where his biography and the stock of his works were clarified step by step. The first publication on Genin in Russian was published in 2008 by Dmitry Severukhin ${ }^{2}$. But at that moment a lot of details of his life after return to the USSR were unknown, even the year of his death (in different sources 1943 or 1939 were used). Unclear was also his artistic development. In 2009 the author found at

1 1st booklet: Robert Genin (1884-1939). Esslingen: Kunstgalerie Esslingen, 1969; 2nd booklet: Robert Genin Gemälde, Pastelle, Aquarelle, Handzeichnungen, Graphik, Illustrierte Bücher, Mappenwerke. Esslingen: Kunstgalerie Esslingen, Mai/Juni 1977; 3rd booklet: Robert Genin 1884-1943. Gemälde, Pastelle, Aquarelle, Zeichnungen, Graphik, Illustrierte Bücher. Eine Werkübersicht. München: Kunstgalerie Esslingen, Mai/Juni 1980.

2 Северюхин, А. Забытое имя. Художник Роберт Генин (1884-1943), Антикварное обозрение, октябрь 2008. 3: 26-29. 
RGALI, Moscow, extensive memories of Alexander Mogilevsky ${ }^{3}$ on Genin's Moscow period. In 2010 a part of his heritage was found - also in Moscow. In 2011 an extensive correspondence of Genin with Karl Im Obersteg was published in connection with an exhibition in Kunstmuseum Basel. ${ }^{4}$ Our further investigations identified several works by Genin in depots of German, Swiss, American and Russian museums and private collections. After being put virtually together, those works showed a clear logic of Genin's artistic development. The author has published the first results in his paper for the Chagall readings (2011) in Vitebsk. ${ }^{5}$ In 2013 an exhibition "Robert Genin. In search of the Paradise: Bali, 1926" followed in three Belorussian museums in Mogiljow, Vitebsk und Minsk. ${ }^{6}$ In 2016 a long article on the Moscow period of Genin was published. ${ }^{7}$ Finally, a comprehensive retrospective exhibition of Genin's work was carried out by Schlossmuseum Murnau in 2019, accompanied by a detailed catalogue ${ }^{8}$ in German and Russian with six articles by Alexej Rodionov, Bernd Fäthke, Sandra Uhrig, Christine Hopfengart, Ralph Jentsch and Henriette Mentha.

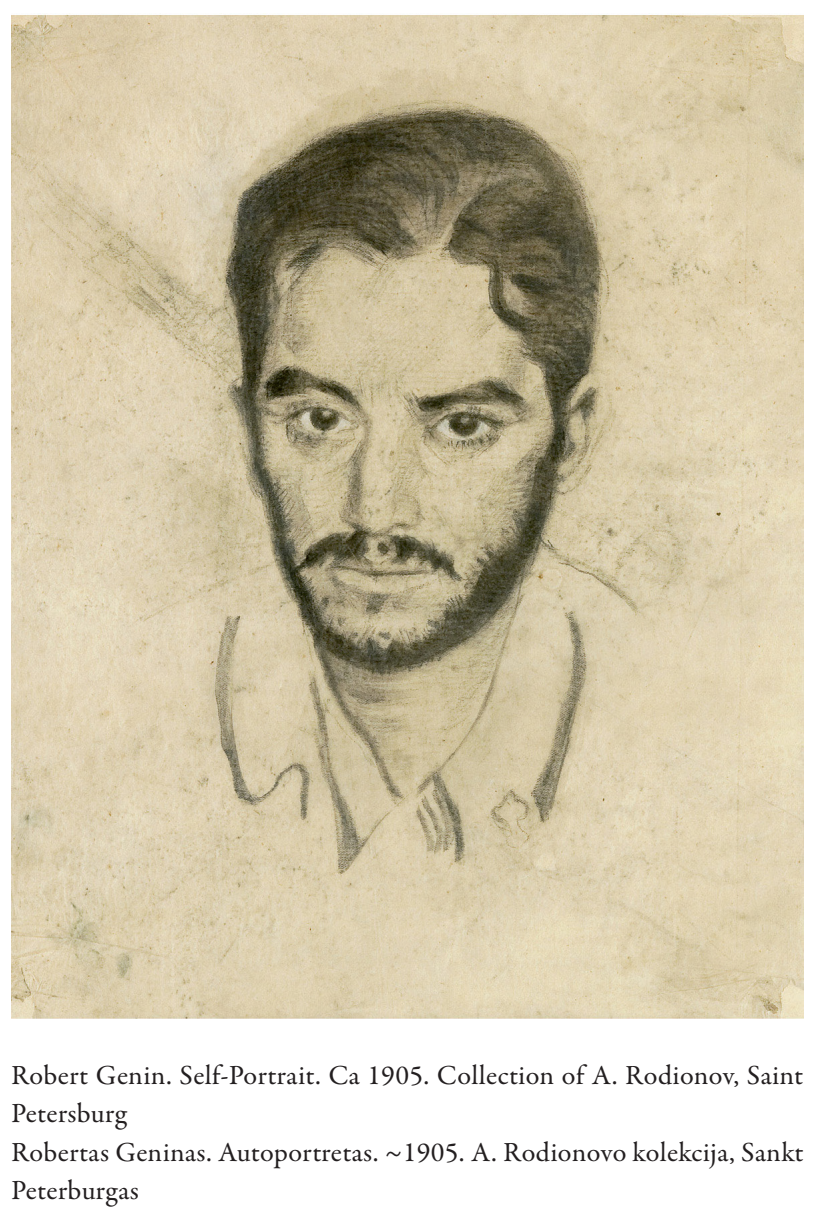

3 Могияевский, А. Воспоминания о Р. А. Генине. 1956. Рукопись. РГААИ, 3056-1-30.

4 Fischer, M. Der Briefwechsel mit Robert Genin (1884-1941). Sie lieber Herr Im Obersteg sind unser Schweizer für alles. Briefwechsel mit Cuno Amiet, Robert Genin, Alexej von Jawlensky, Alexander und Clotilde Sacharoff, Marc Chagall, Ernst Ludwig Kirchner und Wassily Kandinsky in der Sammlung Im Obersteg. Hrsg. von der Stiftung Im Obersteg, Basel: Schwabe Verlag, 2011: 41-75.

5 Родионов, А. Художник Роберт Генин (1884-1941). Творчество и судъба. Бюлметень Музея Марка Шагала, 2011. 19/20: 137-156.

6 Robert Genin. Auf der Suche nach dem Paradies: Bali, 1926. Hrsg. von A. Rodionov. Saint Petersburg, 2013.

7 Родионов, А. Роберт Генин (1884-1941). Последние годы художника (на основе материалов московских архивов, Вестник истории, литературьи, искусства, Москва, 2016. 11: 434-454.

8 Robert Genin (1884-1941). Russischer Expressionist in München. Hrsg. von A. Rodionov und S. Uhrig. Murnau am Staffelsee: Schlossmuseum Murnau, 2019. 
Genin was steadily moving, he was unable to live an ordered, slow-paced life at the same location, as well as he was unable to work always within one and the same manner of painting. In the Munich city archive there are records showing 28 address changes of Genin for the period of 1903-1918 in Munich only, apart from numerous voyages inside Germany, France, Italy, Egypt. 'Temperamental man, easily turning from concentrated state to exulting, laughing, loud laughter which infected the company, hospitable and unconcerned', this portraiture given by Mogilevsky has been repeated also by other people who knew Genin.

The artist Robert Genin was born in a village Vysokoye near Klimovichi in the Region of Mogilev. He studied art in Vilna (1898-1900) and in Odessa (1900-1902). At the end of 1902 he moved to Munich, from where he continued to move intensively throughout Europe. From 1919 on he lived mainly in Berlin and in Ascona, from 1929 on in Paris. In spring 1936 he, full of enthusiasm, moved back to Russia in order to paint frescos on the walls of Moscow's new buildings. In autumn 1941 he committed suicide.

Robert Genin became renowned in 1912, as his portfolio of 20 lithographs 'Figürliche Kompositionen'” was issued. Next year famous Munich gallery Moderne Galerie Heinrich Thannhauser concluded an exclusive contract with the 28-yearold painter and carried out his solo exhibition. Genin became a popular artist and a member of artistic groups (Sema, Neue Münchner Secession, Berliner Secession). He took part in more than 70 exhibitions. His work became the subject of articles by deep art critics like Fritz Burger (1913, 1914), Otto Bratskoven (1927), Paul Fierens (1931), André Warnod (1931), André Salmon (1932), Kasper Niehaus (1932), Alexander Romm (1938).

The manner of Genin changed significantly several times - as a result of both external influence and his internal development. But, as Paul Westheim wrote in his annotation to the booklet of the last solo exhibition of Genin held at Lilienfeld Galleries in New-York in 1936:

'Genin's art is a typical example of how the character of a painter, the deeper tendencies of his soul, will pervade his work so that every painting can be recognized as the product of the same man even though his style undergoes considerable change. With Genin it is the lyrical element which is always present. This lyrical quality can be found even in his early, rhythmical compositions when he was striving for a monumental style under the influence of Puvis de Chavannes and Hans von Marées; again it is the lyric quality in his now famous heads painted in Bali, where, fascinated by the beauty of the country and its people, he worked direct from nature; and still this same lyrical element appears in his latest productions, those dream-like visions such as 'The Fiancee,' 'The Blonde' and 'The Painter' in which, although living in Paris,

9 Robert Genin. Figürliche Kompositionen, 20 Orig.-Lithographien. Vorwort von W. Riezler, München: Delphin-Verlag, 1912. 
the artist betrays his Russian origin more than in any former stage of his development. It is in these late canvases with their fusion of his personal lyricism and the strength of his national character that Genin achieves the most harmonious solution of his artistic and emotional problems' ${ }^{10}$.

Genin's works are widely spread in the world, whereabouts of many are unknown. The painter himself did not take care of his works, their integrity and preservation. Nevertheless, some of them have found ways into museums, among which are the following: Kunstmuseum Basel, Ostdeutsche Galerie (Regensburg), Berlinische Galerie, Museum Ludwig (Köln), Art Institute of Chicago, Von der Heydt Museum (Wuppertal), Lenbachhaus (Munich), Pushkin State Museum of Fine Arts and Russian State Archive of Literature and Arts (RGALI) in Moscow.

\section{Artistic development of Robert Genin}

In his handwritten memoirs ${ }^{11}$ Genin described his departure to Vilna - a somewhat wild teenager from a god-forgotten Belorussian shtetl:

'Was decided to send me to the Drawing school in Vilna as I grew fourteen. Having in mind my numerous copied drawings my grandfather intended to make out of me a proper photographer, who should open an atelier in Klimovichi, despite of the youth. My grandmother cried bitterly as she looked at the carriage taking me away - nobody of ours had up left for the big world to now, and in addition, she had her own opinion regarding me. The day and night I drew in the sledge towards the nearest railway. A horror was waiting for me there. As I, having nothing suspected, have entered the platform, I saw a miracle - a locomotive - and then - ob God! - it gave a whistle. Howling loudly, I threw myself back to the waiting room. This was how it began - it was the first step into the 'big world'. On the road to Vilna I met - after the long years of separation and for the last time - my father, bitter, twisted and lonely odd fellow. He brought me to Vilna and kept teaching that I was no more a master but a poor boy who needs a support of other people and that I should learn to bow. He dragged me to some rich family where in tragic words he started to describe my situation - in outland, without means... Upon that he plucked at my sleeve, reminding of his instructions. In vain: I stood with my head proudly risen and carelessly looking to the pictures on the walls. Bowing I did like never'.

After two years in Vilna he moved to Odessa: 'My meals consisted of bread and tea, I lived in the most suspicious houses together with drinkers and street girls. Yet I took such life as necessary price to pay for the art. Exactly that way I imagined the life of any god-blessed artist. Indeed, soon I became a recognized talent hold in respect and envied by the colleagues.

10 Genin, Exhibition catalogue. Introduction of Paul Westheim. Lilienfeld Galleries, 1936.

11 Genin, R. Large handwritten book [in German]. Private Collection, Saint Petersburg $(54 \times 50 \mathrm{~cm}$, in German). 
Periodically I abandoned myself to composing the poems that were lamenting especially emphatically the fate of a street girl, a dressmaker, an outcast woman. I earned my peanuts in the School by corrections of drawings and in the port where I portrayed elevated fun-seekers also. It happened sometimes that I did not have a crumb of bread in my mouth for days. Then I went, my stomach gurgling, along the beach through the park, where they used to set up evening concerts or cabarets in the open air. I composed - or shed a tear for my hardship - but during these dark nights on the park banks in front of the endless sea my dreams were hot - about the wonderful future in that faraway world which opened behind the horizon and which some day shall open for me its embracement. Great art - unexpected talent - I am painting huge pictures which show the mankind the entire sorrow of this world - my name is being passed from lip to lip - all foreign newspapers praise me in chorus - Paris - and - and marvellous women. Go abroad! - became my idée fixe - I need to get there necessarily - even if I have to go bare foot.'

Genin's works (along with other chosen works) were sent to the Imperial Academy of Arts in Saint Petersburg in $1898^{12}$. Since the School was under the patronage of the Academy, it used to be a regular practice to send the best works there annually. Despite his progress, Genin remembered his years of study in Vilna and Odessa not often, and if he did so, he pointed out that the emphasis had been put there on drawing skills; he remembered endless copying of plaster models. Obviously, the students of the schools had to learn the craft and not the creativity, and it would be strange to expect something else.

After his arrival to Munich, Genin suffered several disappointments. First, he was admitted to the famous private school headed by Anton Ažbe, but left it after a few weeks having realized that there is nothing new he could learn there. Indeed, Ažbe's school was already running down in 1903, partly due to the illness of its founder Anton Ažbe (1862-1905). Another disappointment had to do with the famous Munich masters - Franz Stuck and Franz von Lenbach. This phenomenon was also described by Igor Grabar, who experienced it during his trip to Munich and further on to Paris 6-7 years prior to Genin. Puvis de Chavannes was in Paris, whose works impressed Genin deeper than any other.

Genin inherited from Puvis de Chavannes both neoclassicism and symbolism, as well as his inclination towards monumentality. Like Puvis, Genin felt the attraction to everyday subjects (as scenes of work or rest) which he was raising in his pictures to the high degrees of harmony between the human beings and nature. Although he stopped representing classic naked people in ideal landscapes with the beginning of the Great War, the inclination towards fresco was with him through the entire life. The influence of Puvis de Chavannes is evident in the lithographic portfolio 'Figürliche Kompositionen'

12 Širkaitè, J. Vilniaus piešimo mokykla ir jos mokiniai, Kultūros istorijos tyrinẹjimai. Vilnius: Gervelè, 1997. 3: 201, 224. 
(1912). These compositions were created as sketches for future frescos intended for the new building of Art Museum in Szczecin that was completed in 1913. The frescos were unrealized $^{13}$.

Next year, in 1913, the Moderne

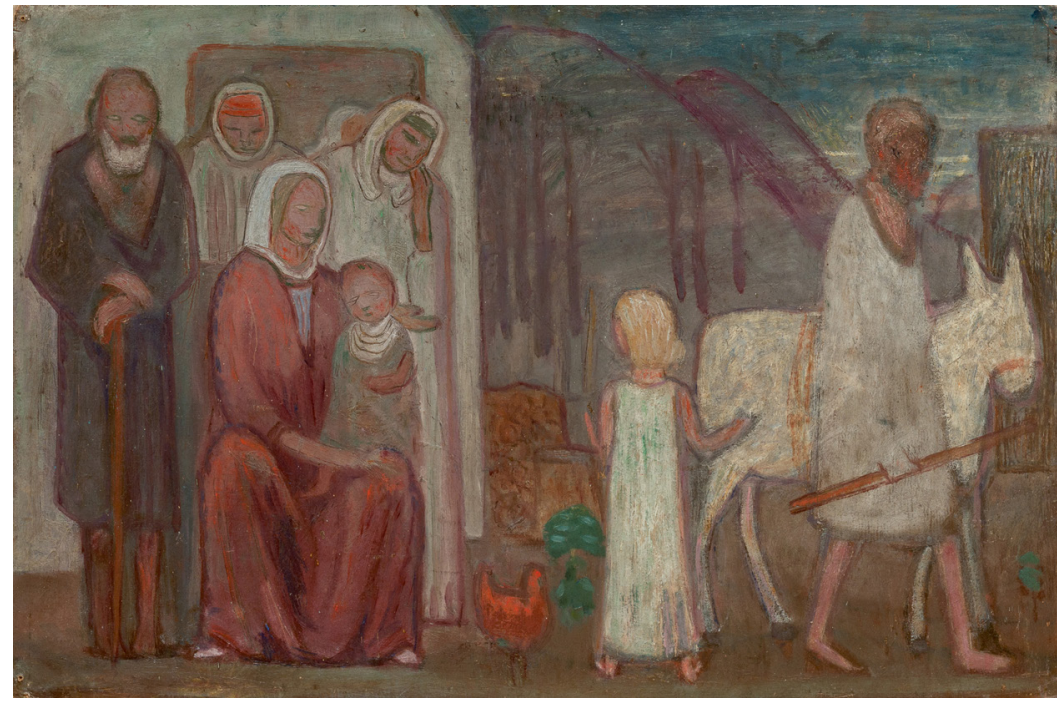

Robert Genin. A Farewell to the Son. Ca 1910. Collection of A. Rodionov, Saint Petersburg Robertas Geninas. Atsisveikinimas su sūnumi. 1910. A. Rodionovo kolekcija, Sankt Peterburgas

Galerie Heinrich Thannhauser concluded an exclusive contract with Genin and carried out his first solo exhibition. The exhibition was successful, Genin became popular, he was invited to take part in different exhibitions in Germany, Switzerland, Netherlands. In 1913 it was ten exhibitions where he participated in, in 1914 it was eight. At the Baltic Exhibition in Malmö, which opened in peacetime - on the 15th May 1914 Genin showed three works. A photo of this exhibition survived: five paintings by Bechteev - three paintings by Genin - five paintings by Kandinsky. At the first exhibition of Neue Münchener Secession Genin showed two paintings, he was a co-founder of this group.

As the war began in August 1914, the utopic ideal harmony of Genin's works lost its ground completely. Genin could not paint any more as before. He brought his new manner to paper in 1915 in his portfolio of 11 war lithographs 'Die Frau' ('The Woman'), which were shown at the second exhibition of the Münchener Neue Secession in summer 1916. Contrary to the 'Figürliche Kompositionen' the chief motive of 'Die Frau' became the tragedy which changed the former paradise idyll. Death, directly or indirectly, is present

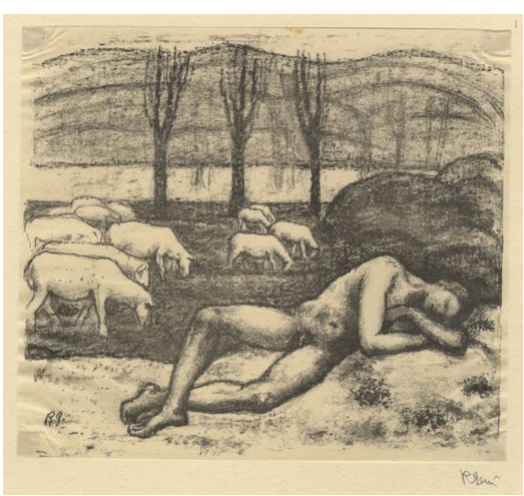

Robert Genin. A Resting Shepherd. From the series 'Figürliche Kompositionen'. 1912. NAMRB Robertas Geninas. Besiilsintis piemuo. Iš serijos „Kompozicijos su figūromis“. 1912. BRNDM

13 Lichtnau, B. „Futuristen im Museum!“. Der Stettiner Museumsstreit im Jahre 1913, Multiplicatio et variatio: Beiträge zur Kunst. Hrsg. von M. Müller. Berlin: Lukas Verlag, 1988: 292-310. 


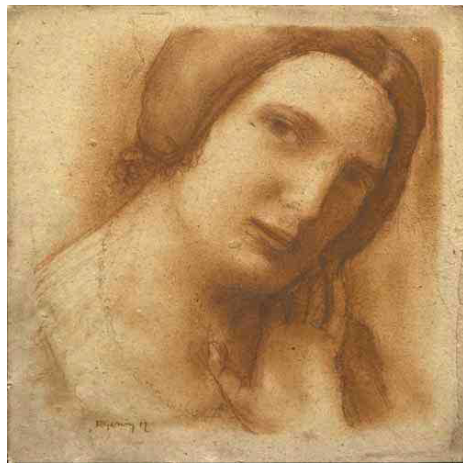

Robert Genin. A Portrait. 1912. Collection of A. Rodionov, Saint Petersburg Robertas Geninas. Portretas. 1912. A. Rodionovo kolekcija, Sankt Peterburgas

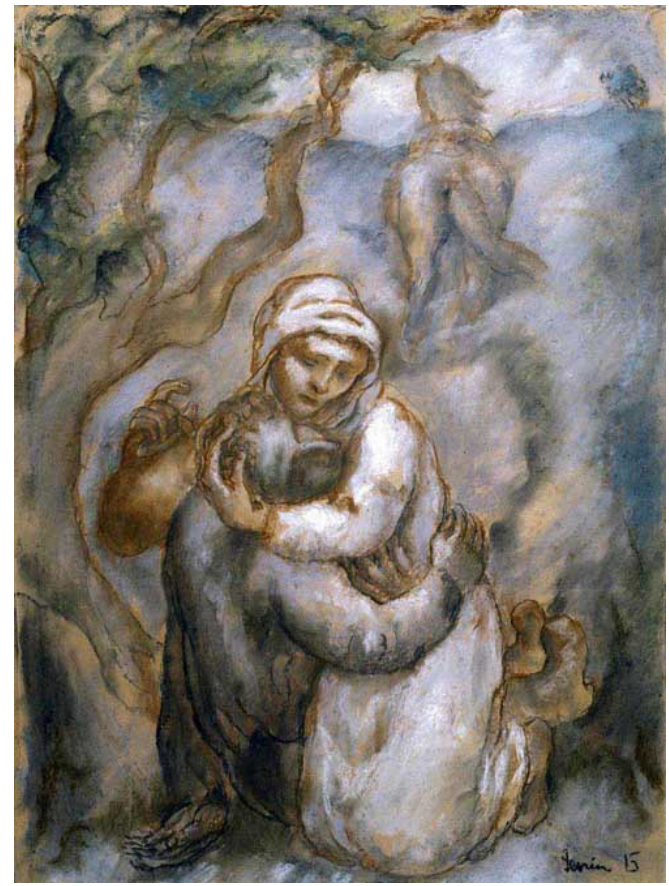

Robert Genin. A Sister. 1915. Collection of A. Rodionov, Saint Petersburg

Robertas Geninas. Sesuo. 1915. A. Rodionovo kolekcija, Sankt Peterburgas will find enough courage to safeguard his art, will let it freely develop from inside, that he will get rid of that too transparent and less fascinating symbolism of his present pictures

during the Great War such things were still possible. The exhibition took place in two floors - painting on the ground floor and graphics on the third. Not everybody approved the changed manner of Genin. August Liebman Mayer wrote, for example:

'Robert Genin from Russia (by the way - which German artist could exhibit now in a country fighting against Germany?) also follows decorative tendencies, but he proceeds not from a religious experience, rather trying to show everyday events in lofty and mystically vague form. And as good as his graphics also this time is, so unlucky is his performance as painter. <...> Now he declares himself too pretentiously, fails with the format, allows other manners - those of early Picasso and Coester - to be too evident, not always holds his high taste in colouring, or tries to create original colour solutions, where it seems inappropriate. <...> One should hope that this by nature romantically gifted artist 
and will give his tender lyrics a possibility of self-expression ${ }^{14}$.

Genin apparently introduced in his paintings bright open colour, which he used to avoid previously, in the years 1917-1918. Further development of Genin in the 1920s and 1930s proved that he was indeed moving - although not directly - but in the direction indicated by Mayer, giving his tender lyrics a possibility of self-expression. In the middle of the 1920s Genin gradually stepped from expressionism to some kind of 'lyric primitivism' like Bonnard and late Pougny also did. Yet before, he went to Berlin - immediately after the war finished at the end of 1918. He presented a number of dry-point etchings series, published by Paul Cassirer and Fritz Gurlitt in 1919-1920: 'Typen aus Berliner Spelunken' together with Michel Fingesten, a series of 30 sheets without common title 'Menschen' and 'Zirkus', as well as

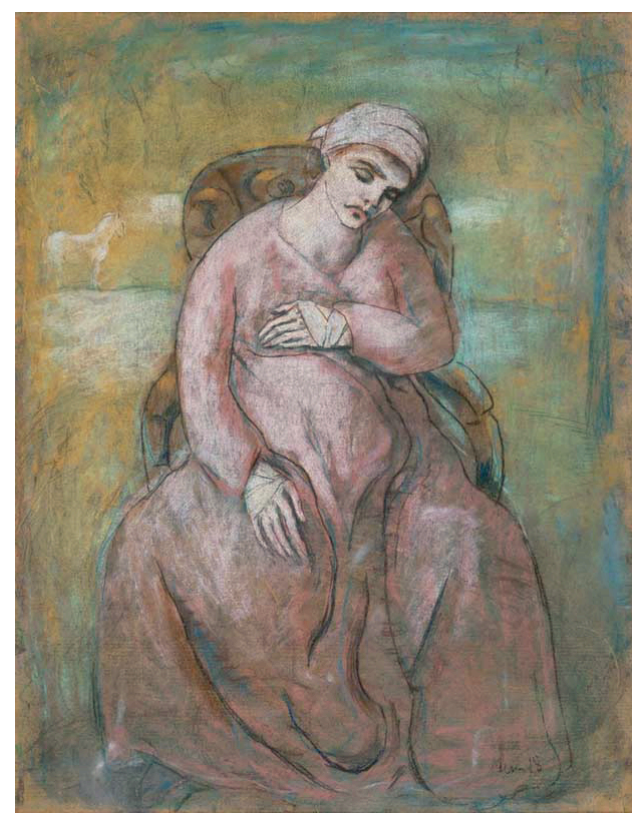

Robert Genin. A Sufferer. 1918. Collection of A. Rodionov, Saint Petersburg

Robertas Geninas. Kenčianti. 1918. A. Rodionovo kolekcija, Sankt Peterburgas his livre d'artiste 'Skizzen und Erinnerungen'.

In the years 1921-1923, Genin illustrated with his etchings and lithographs five books of expressionist writers Hans Bethge, Kasimir Edschmid, Jacob Wasserman. His active work was accompanied by private changes: in 1919, Genin purchased a little house in Ascona and met Margarete Gurth, whom he married soon; in April 1921, their son Mario was born in Ascona. However, Genin was unborn for domesticity household cares were rather boring for him, while free customs of Weimar Republic contributed airily to a quite unchained way of life. Genin had it easier with graphic works than with paintings, but he took painting very seriously and complained having not sufficient time for it. The following paintings survived those that were created at the beginning of the Berlin period: 'Acrobats' (1919, private collection, Wiesbaden), 'The man reading' (1921, presented at the opening of the Berlin branch of the Alfred Flechtheim gallery the same year and afterwards published by him in the Querschnitt under the title 'Charley Chaplin'), as well as a large Self-portrait in pastel from the Feldberg collection (in the Berlinische Galerie now). These works are characterized by the same "looseness" as the works from 1917-1918. The lines are swinging, the paint is light and many-coloured with inclusions of bright, almost 
signal yellow and red. After having opened his gallery in Berlin in October 1921, Flechtheim carried out an exhibition of Genin in January 1922. Critical response came from Willi Wolfradt ${ }^{15}$ and Karl Scheffler:

'Genin exhibiting a number of his paintings at Flechtheim, perfectly corresponds to the atmosphere of this gallery. He is more fine than strong; his painting has spirit, but not fullness, his art is obviously a result of critical perception rather than of naive sensibility. <...> Genin knows the composition rules and is able to build up a painting perfectly; but at a certain stage he stops and he can't lead it further. His painting reminds on aquarelles and pastels, it is subtle and smart, contains sharp hints to some vivid moments. One could call Genin 'essentialist'. That is that he seeks - and often founds - the essence of things; what he - and many others - lacks, is their substance ${ }^{16}$.

By 1923 Genin's painting becomes denser and deeper in colour again, the figures of his characters become plastically more robust as if they would 'crystallize' in the composition (e. g. 'Tearful woman' and 'Young Russian', both reproduced in 'Querschnitt', also 'Parting'; all three in 1923, in different private collections now). In his landscapes of the 1923-1925 Genin managed to achieve an especially nice combi-

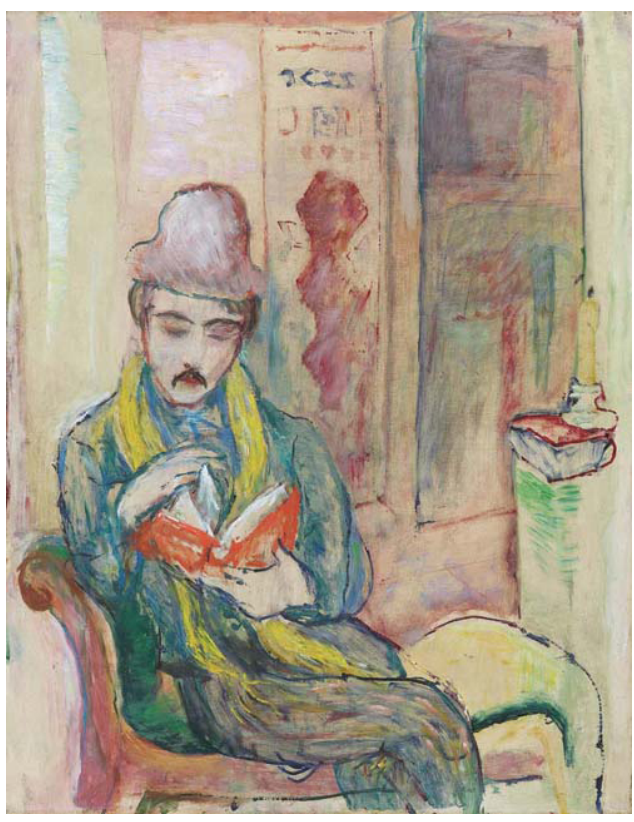

Robert Genin. Charley Chaplin. 1921. Collection of A. Rodionov, Saint Petersburg

Robertas Geninas. Charley'is Chaplinas. 1921. A. Rodionovo kolekcija, Sankt Peterburgas nation of strong composition, deep colouring and original bright palette based on pistachio green, ochre-rose and warm yellow. The 'lyric primitivism' - especially evident in the human figures and animals, which will dominate his work in the 1930s, is already there.

A voyage to Bali that Genin undertook in $1926^{17}$ returned a large array of pastel sketches from nature, based on which upon his arrival to Berlin the artist created a number of remarkable paintings. Fine pastel drawings, mainly depicting graceful Balinese girls, immediately became popular among the collectors. From the paintings of this period only four have survived, two of them descend from Karl Im Obersteg collection and are now in Art Museum Basel. Other four paintings dated 19261927 are known according to exhibition

15 Ausstellungen. Berlin [Wolfradt, W.], Kunstblatt, 1922. 2: 89-90.

16 Kunstausstellungen [Scheffler, K.], Kunst und Künstler, 1922. 7: 252.

17 Robert Genin. Auf der Suche nach dem Paradies: Bali, 1926. Hrsg. von A. Rodionov. Saint Petersburg, 2013. 
catalogues of Berliner Secession and publications in art magazines. As one can judge from the survived works and the black and white illustrations, Genin's paintings of this period were perfectly composed (as always) and executed in cheerful colours. These are works of a mature master, who has found himself. Indeed, Genin wrote at that time: 'Finally I have my own material and I am making my best paintings'18. Critics have also accepted the new works of Genin favourably, e.g. Otto Brattskoven ${ }^{19}$ and Max Osborn:

'With their decorative splendour of light colours, advantageously and convincing are showing up the large paintings that Robert Genin owes to his voyage to the island of Bali. We see how an actor and a dancer - in their exotic multi-coloured covers and with a strange detachment of noble gesture - depicted in an amazingly thought-out and harmonic composition'20.

Genin was elected a member of Berliner Secession in December 1926 (he was regularly exhibiting with this group since 1922). In 1928 his book 'The Faraway Island' was published in a large run of ca 200,000 copies $^{21}$. His pictures were desirable, the peak of popularity seemed to be achieved. Something went wrong however. He made a lot of efforts for correspondence with Swiss authorities regarding entry permission; his house in Ascona that was under burden of hypothec and which he rented required attention as well. His girlfriends, whom the affectionate artist was fond of spending time with, also needed his attention. Genin divorced Margarete in 1927. The planned a solo exhibition at Thannhauser gallery (planned at first for autumn 1927, then for spring 1928, then for

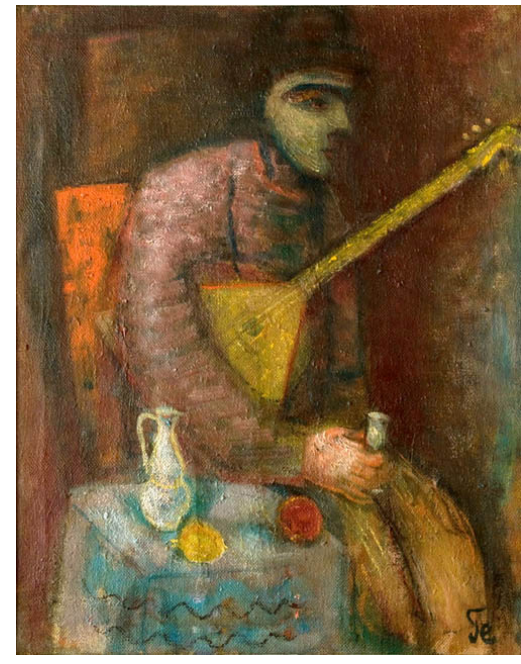

Robert Genin. Balalaika Player. Ca 1924. Collection of A. Rodionov, Saint Petersburg Robertas Geninas. Balalaikininkas. 1924 . A. Rodionovo kolekcija, Sankt Peterburgas

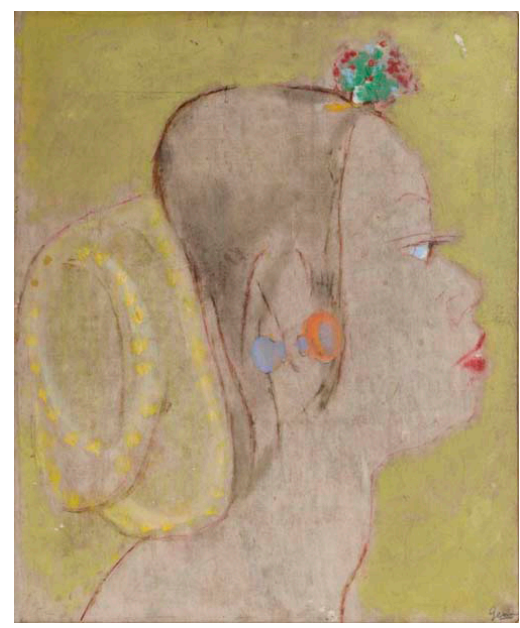

Robert Genin. A Head of Balinese. Ca 1926. Collection of A. Rodionov, Saint Petersburg Robertas Geninas. Balietės galvutè. 1926. A. Rodionovo kolekcija, Sankt Peterburgas

18 Letter of Genin from Berlin to Karl Im Obersteg in Basel, undated [August-September 1926]. Stiftung Im Obersteg, Depositum im Kunstmuseum Basel.

19 Brattskoven, O. Zu Robert Genins „Hahnenkampf auf Bali“, Die Künstler-Selbsthilfe (Zeitschrift für Kunst und Literatur). 1927. 2, I. Jg., April-Mai: 26-27.

20 Deutsche Kunst und Dekoration, 1926-1927. 59: 213.

21 Genin, R. Die Ferne Insel. Aufzeichnungen von meiner Fahrt nach Bali in Wort und Bild. Berlin: Wegweiser-Verlag, Volksverband der Bücherfreunde, 1928. 
autumn 1928) did not take place. Genin with his girlfriend Genia Ines moved to Paris to conquer new peaks in 1929. It happened almost at that time when the entire world was shaken by the heavy financial crisis, which marked the start of the Great Depression.

According to Karl With, his friend, Genin was 'of carefree and ebullient temperament, creatively be labored under a severe emotional strain: suffering from a phobia to exhibit his works. He had not dared to exhibit publicly once more, he feared he could not live up to what the art world expected from him. So frustrating was his fearful anxiety, that he did not even care to preserve his art works, which he left littered on the floor of his studio; fragile pastels were badly smudged, drawings crumpled, paintings neither properly stretched nor framed'22.

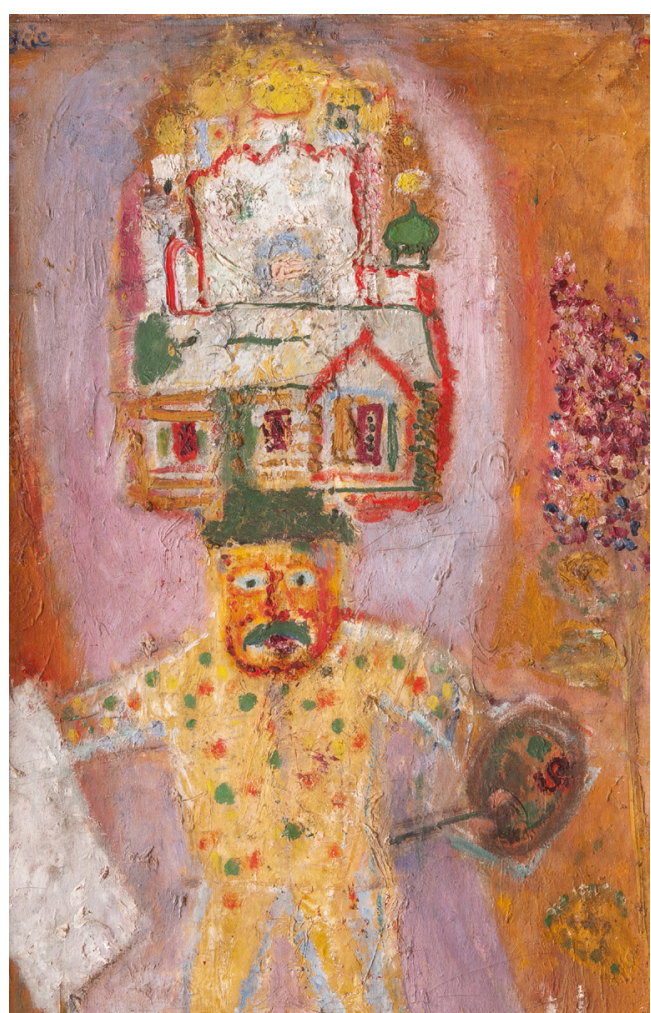

Robert Genin. A Painter. 1930. Collection of A. Rodionov, Saint Petersburg

Robertas Geninas. Tapytojas. 1930. A. Rodionovo kolekcija, Sankt Peterburgas
Nevertheless, a solo exhibition of Genin opened on the 28th of November 1931 in Paris, at Jacques Bonjean gallery. Carried out without a catalogue, the exhibition gathered highly approving press - e.g. in the contributions by Paul Fierens, André Warnod, André Salmon:

'Striding back towards his past (or, rather, his subconscious) and the village whose isbas and bulbous cupolas of gold return to him in dreams, Guenine recaptures something of the fervour of the icon-painters, their limpid tones - tender pinks and pistachio-greens, and their way of portraying not nature herself but her message to the heart and spirit. Perspective is of little service to this artist; his pictures built up in, as they were, a spatial dimension of the mind. They are images like cast onto a screen that is other than the canvas, and continue their existence on another plane. Guenine's work is a product of intuition' 23 .

'Poetry overthrows all the rules, the poetry would be the one that rules. A painting of Guénine is poetry, full of enthusiasm and

22 With, K. Autobiography of Ideas, Lebenserinnerungen eines außergewöhnlichen Kunstgelehrten. Hrsg. von R. Jaeger. Berlin: Gebr. Mann Verlag, 1997: 194-195.

23 Fierens, P. Guenine or Childhood Regained, Formes, 1931. 19: 157-161. 
joy, intimate, charming and gentle, which through the play of colours and grace of arabesques becomes a feast for the eyes ${ }^{24}$.

'It could be possible to write about this artist, talking about pure painting only, and that is seldom'25.

A month prior to the exhibition a Swiss collector Emil Kadé concluded with Genin a long-term contract and purchased simultaneously not less than 22 works. The paintings of the period 1928-1931 shown at Bonjean developed in natural way in the same direction as the works of 1925-1927: harmonic, of moderate brightness colouring based on warm (yellow, red, green) tones, uncomplicated but firmly builtup monumental composition, primitivistic, playing stylization of figures and objects. All that was united by the lyric talent of the artist.

There is not much information concerning the last Paris' years of Genin (1932March 1936). He prepared and carried out two personal exhibitions: the one in Amsterdam in 1933, the other in New York in 1936, which demonstrated chiefly his previous achievements - the Balinese pastels and the paintings from the beginning of the 1930s.

Three known paintings of the period 19331935 (all in a private collection, Saint Petersburg) allow suggesting that the artist worked without pressure, rather for his own pleasure. They are solved in charming colour, they contain a lot of excessive small details. Karl Scheffler, who in 1922 was criticizing Genin's paintings for lack of spontaneity and for lack of substance, now should have been satisfied. There is a lot of play in those paintings: the artist plays both with his subjects and with his painting techniques. Such a play seems to match the eccentric temperament of Genin better than the serious and meaningful pathos of his early works from 1913 did. Genin's paintings of the 1930s evoke an impression of harmony; the artist, who was intensively changing during the last 30 years, seems to have finally found the manner which complies with his inclinations.

As we have observed already, the prolonged regular life was not Genin's habit. In the March of 1936 he got the Soviet passport and left for Moscow. Prior to his departure, Genin painted

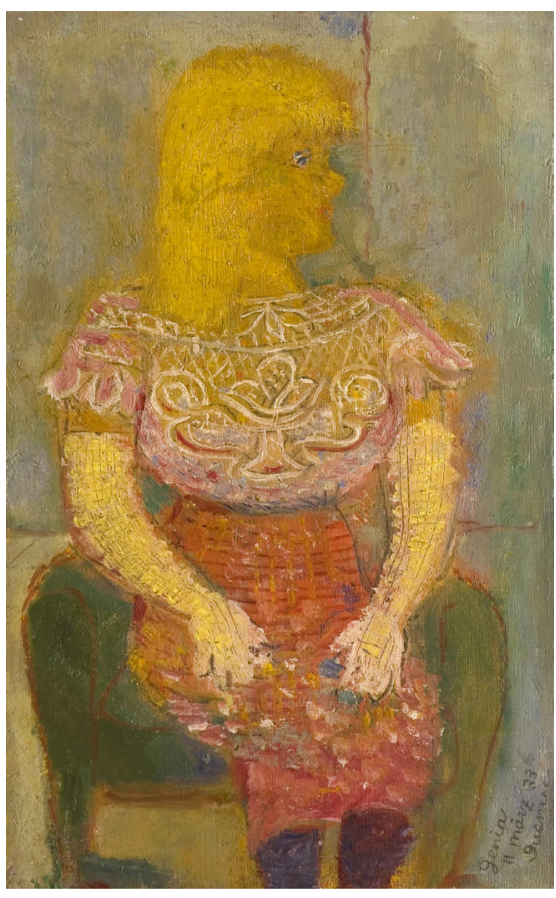

Robert Genin. A Painter. 1930. Collection of A. Rodionov, Saint Petersburg

Robertas Geninas. Tapytojas. 1930. A. Rodionovo kolekcija, Sankt Peterburgas

24 Warnod, A. De la Ruche à Java... et retour. Guénine évoque ses souvenirs d'enfance, Comoedia, 28 11 1931: 3.

25 Salmon, A. Deux peintres: Guénine et Kisling, Bravo, Janvier 1932: 46. 


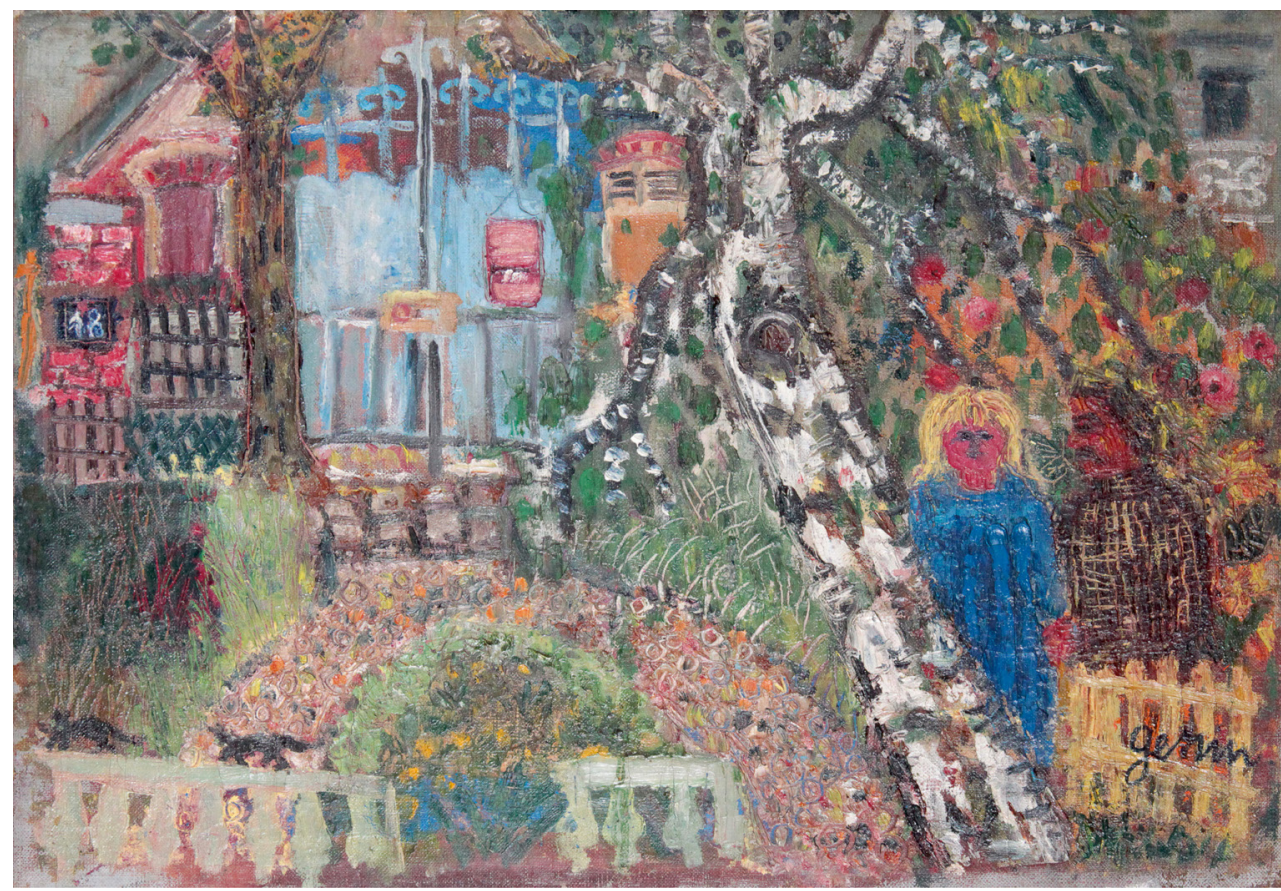

Robert Genin. A Couple in the Garden (Self-Portait with Genia). Ca 1935. Collection of A. Rodionov, Saint Petersburg Robertas Geninas. Pora sode (Autoportretas su Genia). 1935. A. Rodionovo kolekcija, Sankt Peterburgas

walls of a communist club in Paris by his frescoes. Departing to the USSR was not uncommon at that time; in Paris there was a movement of 'vozvraschentsy' (returners) and many well-known artists returned to Russia by that time: Sergey Prokofiev, Ivan Bilibin, Vasily Shukhaev, a bit later - Marina Tsvetaeva.

The heavy economic crisis that covered the Western world forced people to think about alternatives, and such an alternative seemed to be the young state that declared completely new principles of its foundation. Since his beggary youth Genin had adopted communist ideas, he was always inclining towards utopic phantasies; but in order to understand where he was really going to, an analytic mind was necessary. It is likely that the old Berlin acquaintances of Genin - e.g. El Lissitsky who was appointed Chief Artist of $V S K h V$ (All-Union Agricultural Exhibition, Russian: Всесоюзная Сельско-Хозяйственная Выставка - ВСХВ) - described him the perspectives so attractive that he came with the firm intention to paint frescoes on walls of Moscow's new buildings. Without going into details on all windings of the Moscow period of Genin ${ }^{26}$, let us remember that in years 1936-1938 he passionately painted a fresco for the face of pavilion 'Sovkhoses' of $V S K h V$ until decided to remove it due to repurposing of the pavilion.

26 Родионов, А. Роберт Генин (1884-1941). Последние годы художника (на основе материалов московских архивов, Вестник истории, митературы, искусства, Москва, 2016. 11: 434-454. 
In years 1939-1941 he, passionately again, worked on interior frescos for the Palace of Soviets, having realized his old dream about collective labour - until the war terminated that project as well. On the 16th of August 1941 Genin committed suicide. Only a few images have survived to give an idea of his work in Moscow: photos of the almost finished fresco at $V S K h V$ in a strong foreshortening; a photo of happy Robert L'vovich in front of the cartoons for that fresco; two pencil drawings and one pastel drawing 'Spain refugees', stored at The Russian State Archive of Literature and Arts (РГА $\Lambda И)$.

\section{Abreviations \\ VSKhV - All-Union Agricultural Exhibition (Russian: BCXB - Всесоюзная сельско-хозяйственная выставка) \\ РГА ИИ - The Russian State Archive of Literature and Arts (Russian: Российский государственный архив митературы и искусства) \\ BRNDM - Baltarusijos Respublikos nacionalinis dailès muziejus \\ NAMRB - National Art Museum of the Republic of Belarus}

Received 2 June 2019

Accepted 13 November 2019

\section{Sources and Bibliography}

1. Ausstellungen. Berlin [Wolfradt, W.]. Kunstblatt, 1922. 2: 89-90.

2. Brattskoven, O. Zu Robert Genins „Hahnenkampf auf Bali“. Die Künstler-Selbsthilfe (Zeitschrift für Kunst und Literatur). 1927. 2, I. Jg., April-Mai: 26-27.

3. Deutsche Kunst und Dekoration, 1926-1927. 59: 213.

4. Fierens, P. Guenine or Childhood Regained. Formes, 1931. 19: 157-161.

5. Fischer, M. Der Briefwechsel mit Robert Genin (1884-1941). Sie lieber Herr Im Obersteg sind unser Schweizer für alles. Briefwechsel mit Cuno Amiet, Robert Genin, Alexej von Jawlensky, Alexander und Clotilde Sacharoff, Marc Chagall, Ernst Ludwig Kirchner und Wassily Kandinsky in der Sammlung Im Obersteg. Hrsg. von der Stiftung Im Obersteg. Basel: Schwabe Verlag, 2011: 41-75.

6. Genin, Exhibition catalogue. Introduction of Paul Westheim. Lilienfeld Galleries, 1936.

7. Genin, R. Die Ferne Insel. Aufzeichnungen von meiner Fahrt nach Bali in Wort und Bild. Berlin: Wegweiser-Verlag, Volksverband der Bücherfreunde, 1928.

8. Genin, R. Large handwritten book [in German]. Private Collection, Saint Petersburg.

9. Kunstausstellungen [Scheffler, K.]. Kunst und Künstler, 1922. 7: 252.

10. Letter of Genin from Berlin to Karl Im Obersteg in Basel, undated [August-September 1926]. Stiftung Im Obersteg, Depositum im Kunstmuseum Basel.

11. Lichtnau, B. „Futuristen im Museum!“. Der Stettiner Museumsstreit im Jahre 1913. Multiplicatio et variatio: Beiträge zur Kunst. Hrsg. von M. Müller. Berlin: Lukas Verlag, 1988: 292-310.

12. Münchener Brief [Mayer, A. L.]. Kunstchronik - Wochenschrift für Kunst und Kunstgewerbe, 30111917. 9: 85 .

13. Robert Genin (1884-1939). Esslingen: Kunstgalerie Esslingen [1969].

14. Robert Genin (1884-1941). Russischer Expressionist in München. Hrsg. von A. Rodionov und S. Uhrig. Murnau am Staffelsee: Schlossmuseum Murnau, 2019. 
15. Robert Genin 1884-1943. Gemälde, Pastelle, Aquarelle, Zeichnungen, Graphik, Illustrierte Bücher. Eine Werkübersicht. München: Kunstgalerie Esslingen, Mai/Juni 1980.

16. Robert Genin. Auf der Suche nach dem Paradies: Bali, 1926. Hrsg. von A. Rodionov. Saint Petersburg, 2013.

17. Robert Genin. Figürliche Kompositionen, 20 Orig.-Lithographien. Vorwort von W. Riezler, München: Delphin-Verlag, 1912.

18. Robert Genin. Gemälde, Pastelle, Aquarelle, Handzeichnungen, Graphik, Illustrierte Bücher, Mappenwerke. Esslingen: Kunstgalerie Esslingen, Mai/Juni 1977.

19. Salmon, A. Deux peintres: Guénine et Kisling. Bravo, Janvier 1932: 46.

20. Šrkaitė, J. Académie de Vilna - Vilniaus piešimo mokykla 1866-1915 / Vilnius Drawing School 1866-1915. Parodos katalogas. Exhibition Catalogue. Vilnius: Lietuvos kultūros tyrimų institutas, 2018.

21. Širkaitė, J. Vilniaus piešimo mokykla (1866-1915). Vilnius: Lietuvos kultūros tyrimų institutas, 2018.

22. Širkaitè, J. Vilniaus piešimo mokykla ir jos mokiniai. Kultūros istorijos tyrinẹjimai. Vilnius: Gervelè, 1997.

3: $166-229$.

23. Warnod, A. De la Ruche à Java... et retour. Guénine évoque ses souvenirs d'enfance. Comoedia. 28 11 1931: 3.

24. With, K. Autobiography of Ideas, Lebenserinnerungen eines außergewöhnlichen Kunstgelehrten. Hrsg. von R. Jaeger. Berlin: Gebr. Mann Verlag, 1997: 194-195.

25. Могилевский, А. Воспоминания о Р. А. Генине. 1956. Рукопись. РГААИ, 3056-1-30.

26. Родионов, А. Роберт Генин (1884-1941). Последние годы художника (на основе материалов московских архивов. Вестник истории, литературьь, искусства. Москва, 2016. 11: 434-454.

27. Родионов, А. Художник Роберт Генин (1884-1941). Творчество и судьба. Бюлметень Музея Марка Шагала, 2011. 19/20: 137-156.

28. Северюхин, А. Забьтое имя. Художник Роберт Генин (1884-1943). Антикварное обозрение, октябрь 2008. 3: 26-29.

\section{Aleksejus Rodionovas}

\section{Kometa vardu Geninas}

\section{Santrauka}

Straipsnyje pristatoma ligi šiol mažai pažinta Mogiliove gimusio Vilniaus piešimo mokyklos auklètinio, vèliau gyvenusio ir kūrusio daugiausia Miunchene, tapytojo ir grafiko Roberto Genino (1884-1941) asmenybè. Menininko biografijos vingiai ir kūrybos kelias rekonstruoti remiantis autoriaus ịvairiuose pasaulio muziejuose bei privačiose kolekcijose surastais dailininko darbais, jo surengtų dailès parodų analize bei kritikų atsiliepimais. Sukaupta medžiaga leido autoriui ištyrinèti jo kūrybos vingius ir išskirti pagrindines stilistines dailininko kūrybos kryptis, nustatyti atskirus jos laikotarpius. 1911-1914 m. Geninas kūrè daugiausia grafines daugiafigūres kompozicijas neoklasicizmo ịtakoje, daugeliui kūrinių suteikdamas simbolinę prasmę. 1915-1924 m. dailininkas atsidavè ekspresionistinei išraiškai, o 1925-1935 m. jo tapyboje vyravo lyrinėmis nuotaikomis persmelktas primityvizmas. Remiantis šia Genino kūrybos periodizacija ir stilistinèmis tendencijomis, straipsnio autoriui pavyko nustatyti daugelio nedatuotų kūrinių sukūrimo laiką bei aplinkybes, nulemusias siužetų įvairovę.

RAKTAŽODŽIAI: Robertas Geninas, dailininkas, tapyba, neoklasicizmas, ekspresionizmas, Mogiliovas, Vilnius, Odesa, Berlynas, Miunchenas, Paryžius, Maskva 